\title{
Implementation of acute care surgery model at a private institution: Our experience over a period of 6 months
}

\author{
Bhavik Patel*, Craig Harris and Damien Petersen \\ St Andrew's War Memorial Hospital, Spring Hill, Australia
}

\begin{abstract}
Background: Acute Care Surgery units are an integral part of most tertiary Australian and New Zealand public hospital services. Several papers have outlined the importance of these units in a public hospital set up. However, there is minimal data on the implementation and outcomes of this model of care in a private hospital set-up.
\end{abstract}

Methods: We set up a dedicated unit to evaluate the outcomes of acute care surgery in a private hospital setting. Three fellows of the Royal Australasian College of Surgeons were an integral part of the roster. Following ethics approval data was collected prospectively over a period of 6 months.

Results: Over a period of 6 months there were 51 patients, 31 males with age range 11 to 90, American Society of Anaesthesiology grades from $1 \mathrm{E}$ to $4 \mathrm{E}$. Average theatre access times ranged from 30 to 500 minutes depending upon time of presentation to emergency department and theatre availability. However, all patients requiring operative intervention underwent surgery prior to completion of 24 hours as an inpatient. Seven patients were managed with non-operative intervention. Two patients required readmission for a post-operative event not requiring surgical intervention.

Conclusions: Given the increase in work load of acute care surgical units at public hospital there might be potential delays in access to operating theatres and thus increasing length of in hospital stay. Implementation of the acute care surgery model at private hospital set up might lead to overcome these potential road blocks.

\section{Introduction}

The introduction of Acute Care Surgical Units across major hospitals in Australia and New Zealand has brought about a paradigm shift in the management of emergency general surgical patients [1-3]. However, with increase in the work load of acute care surgical units at public hospitals there might be potential delays in access to operating theatres and thus increase length of in hospital stay [4]. Private hospitals do provide acute and emergency care, however there is minimal data on the implementation and outcomes of acute care units in a private hospital set-up in Australia and New Zealand.

\section{Methods}

\section{System}

We set up a dedicated unit to evaluate the outcomes of acute care surgery in a private hospital setting. The institution is a 250 bedded hospital with 24-hour Emergency, Intensive Care and Radiology Unit back up in a metropolitan area. The institution does not deal with trauma patients as there is a major trauma center in the vicinity. There are 13 theatres with one hybrid suite. Following approval from the Hospital Ethics committee, data was collected on all patients following consent in a prospective database. The data was collected and reported as per the Standards for Quality Improvement Reporting Excellence (SQUIRE) criteria.

Three General Surgical Fellows of the Royal Australasian College of Surgeons were an integral part of 24 hour on call roster including weekends. Two of the fellows have regular list at the hospital and do have the ability to add emergency general surgical procedures to the end of their list.

\section{Results}

Over a period of 6 months there were 51 patients, 31 males with age range 11 to 90, American Society of Anaesthesiology grades from $1 \mathrm{E}$ to $4 \mathrm{E}$. Average theatre access times ranged from 30 to 500 minutes depending upon time of presentation to emergency department and theatre availability. However, all patients requiring operative intervention underwent surgery prior to completion of 24 hours as an inpatient. The range for length of in hospital stay was 1-7 days.

All patients managed under the unit with their demographics are shown in Table 1.

Seven patients were managed with non-operative intervention. There was no representation, operation, morbidity or mortality in this subset.

Two patients required readmission for a post-operative event not requiring surgical intervention.

One was a known smoker who presented with post-operative pain and fever on Day 2 of discharge following laparoscopic cholecystectomy and intra operative cholangiogram for acute calculous cholecystitis. A Computed tomography was suggestive of bilateral atelectasis which settled with intense physiotherapy for 72 hours.

*Correspondence to: Bhavik Patel, St Andrew's War Memorial Hospital, Spring Hill, Brisbane 4000, Australia, Tel: 61 448119447; E-mail: drbhavikpatel@ hotmail.com

Received: October 26, 2018; Accepted: November 24, 2018; Published: November 27, 2018 
Patel B (2018) Implementation of acute care surgery model at a private institution: Our experience over a period of 6 months

Table 1. Demographics of patient cohort

\begin{tabular}{|c|c|c|c|c|c|}
\hline Age & Gender & Diagnosis & ASA & Intervention/Outcome & Length of stay/Complication \\
\hline 23 & M & $\begin{array}{l}\text { Acute } \\
\text { Appendicitis }\end{array}$ & IE & $\begin{array}{l}\text { Laparoscopic Appendicectomy } \\
\text { Discharge }\end{array}$ & 2 days \\
\hline 33 & M & $\begin{array}{l}\text { Acute } \\
\text { Appendicitis }\end{array}$ & IE & $\begin{array}{l}\text { Laparoscopic Appendicectomy } \\
\text { Discharge }\end{array}$ & 2 days \\
\hline 62 & M & Acute cholecystitis & IIIE & $\begin{array}{l}\text { Laparoscopic Cholecystectomy and } \\
\text { cholangiogram } \\
\text { Discharge }\end{array}$ & 2 days \\
\hline 90 & $\mathrm{~F}$ & Adhesive Small Bowel Obstruction & III & $\begin{array}{l}\text { Gastrograffin } \\
\text { Discharge }\end{array}$ & 3 days \\
\hline 29 & $\mathrm{~F}$ & $\begin{array}{l}\text { Acute } \\
\text { Appendicitis }\end{array}$ & IE & $\begin{array}{l}\text { Laparoscopic Appendicectomy } \\
\text { Discharge }\end{array}$ & 2 days \\
\hline 59 & $\mathrm{~F}$ & Acute appendicitis & IE & $\begin{array}{l}\text { Laparoscopic Appendicectomy } \\
\text { Discharge }\end{array}$ & 3 days \\
\hline 96 & M & Diverticulitis & III & $\begin{array}{l}\text { Intravenous } \\
\text { Antibiotics, } \\
\text { Discharge }\end{array}$ & 3 days \\
\hline 86 & M & Diverticulitis & III & $\begin{array}{l}\text { Intravenous Antibiotics, } \\
\text { Discharge }\end{array}$ & 3 days \\
\hline 14 & M & $\begin{array}{l}\text { Acute } \\
\text { Appendicitis }\end{array}$ & IE & $\begin{array}{l}\text { Laparoscopic Appendicectomy } \\
\text { Discharge }\end{array}$ & 2 days \\
\hline 70 & M & Perforated Appendicitis & IIIE & $\begin{array}{l}\text { Laparoscopic Appendicectomy } \\
\text { Discharge }\end{array}$ & 3 days, urinary retention \\
\hline 70 & M & Gall Stone Pancreatitis & IIIE & $\begin{array}{l}\text { Laparoscopic Cholecystectomy cholangiogram } \\
\text { Discharge }\end{array}$ & 2 days \\
\hline 34 & $\mathrm{~F}$ & Umbilical hernia & IIE & $\begin{array}{l}\text { Umbilical Hernia Repair } \\
\text { Discharge }\end{array}$ & 2 days \\
\hline 56 & M & Adhesive Small Bowel Obstruction & III & $\begin{array}{l}\text { Gastrograffin } \\
\text { Discharge }\end{array}$ & 2 days \\
\hline 41 & M & Perianal abscess & IE & $\begin{array}{l}\text { Incision and Drainage } \\
\text { Discharge }\end{array}$ & 2 days \\
\hline 60 & M & Diverticulitis & II & $\begin{array}{l}\text { Intravenous Antibiotics } \\
\text { Discharge }\end{array}$ & 2 days \\
\hline 58 & M & Acute cholecystitis & IIE & $\begin{array}{l}\text { Laparoscopic Cholecystectomy Cholangiogram } \\
\text { Discharge }\end{array}$ & 2 days, readmit consolidation \\
\hline 58 & $\mathrm{~F}$ & $\begin{array}{l}\text { Alcohol induced } \\
\text { Pancreatitis }\end{array}$ & II & Discharge & 2 days \\
\hline 41 & M & $\begin{array}{l}\text { Acute } \\
\text { Appendicitis }\end{array}$ & IE & $\begin{array}{l}\text { Laparoscopic Appendicectomy } \\
\text { Discharge }\end{array}$ & 3 days \\
\hline 11 & M & Mesenteric addenitis & I & $\begin{array}{l}\text { Observation } \\
\text { Discharge }\end{array}$ & 2 days \\
\hline 52 & $\mathrm{~F}$ & Perianal abscess & IIE & $\begin{array}{l}\text { Incision and Drainage } \\
\text { Discharge }\end{array}$ & 2 days \\
\hline 84 & $\mathrm{~F}$ & Small Bowel Obstruction & IIIE & Laparotomy and band division & 2 days \\
\hline 58 & F & Acute cholecystitis & IIE & $\begin{array}{l}\text { Laparoscopic Cholecystectomy } \\
\text { Cholangiogram } \\
\text { Discharge }\end{array}$ & 2 days \\
\hline 60 & $\mathrm{~F}$ & Strangulated umbilical hernia & IIE & $\begin{array}{l}\text { Open Umbilical hernia repair } \\
\text { Discharge }\end{array}$ & 3 days \\
\hline 57 & M & Diverticulitis & II & $\begin{array}{l}\text { Intravenous } \\
\text { Antibiotics, } \\
\text { Discharge }\end{array}$ & 3 days \\
\hline 35 & M & Infected sebaceous cyst & IIE & $\begin{array}{l}\text { Incision and Drainage } \\
\text { Discharge }\end{array}$ & 1 day \\
\hline 44 & M & $\begin{array}{l}\text { Recurrent non obstructed } \\
\text { epigastric hernia }\end{array}$ & II & Observation & 2 days \\
\hline 43 & $\mathrm{~F}$ & Acute Cholecystitis & IIE & $\begin{array}{l}\text { Laparoscopic cholecystectomy } \\
\text { Cholangiogram } \\
\text { Discharge }\end{array}$ & 2 days \\
\hline 66 & M & $\begin{array}{l}\text { Perforated } \\
\text { Appendicitis }\end{array}$ & IIIE & $\begin{array}{l}\text { Laparoscopic Adhesiolysis and Appendicectomy } \\
\text { Discharge }\end{array}$ & 5 days \\
\hline 56 & $\mathrm{~F}$ & Acute cholecystitis & IE & $\begin{array}{l}\text { Laparoscopic cholecystectomy } \\
\text { Cholangiogram } \\
\text { Discharge }\end{array}$ & 2 days \\
\hline 28 & $\mathrm{~F}$ & Small Bowel Obstruction & I & $\begin{array}{l}\text { Gastrograffin } \\
\text { Discharge }\end{array}$ & 2 days \\
\hline 70 & M & Acalulous cholecystitis & III & $\begin{array}{l}\text { Intravenous Antibiotics } \\
\text { Discharge }\end{array}$ & 5 days \\
\hline
\end{tabular}




\begin{tabular}{|c|c|c|c|c|c|}
\hline 33 & $\mathrm{~F}$ & Appendicitis & IIE & $\begin{array}{l}\text { Laparoscopic Appendicectomy } \\
\text { Discharge }\end{array}$ & 2 days \\
\hline 88 & M & SBO & IVE & $\begin{array}{l}\text { Laparotomy- Band Adhesion } \\
\text { Discharge }\end{array}$ & 5 days \\
\hline 66 & M & Diverticulitis & IIE & $\begin{array}{l}\text { Laparoscopic Anterior Resection } \\
\text { Discharge }\end{array}$ & 7 days \\
\hline 66 & M & Pancreatitis & I & $\begin{array}{l}\text { Observation } \\
\text { Discharge }\end{array}$ & 5 days \\
\hline 53 & $\mathrm{~F}$ & Appendicitis & IE & $\begin{array}{l}\text { Laparoscopic Appendicectomy } \\
\text { Discharge }\end{array}$ & 3 days \\
\hline 22 & M & Acalulous cholecystitis & I & $\begin{array}{l}\text { Observation } \\
\text { Discharge }\end{array}$ & 3 days \\
\hline 38 & M & Fissure in ano & I & $\begin{array}{l}\text { Conservative } \\
\text { Discharge }\end{array}$ & 1 day \\
\hline 33 & $\mathrm{~F}$ & Biliary colic & IE & $\begin{array}{l}\text { Laparoscopic cholecystectomy } \\
\text { Cholangiogram } \\
\text { Discharge }\end{array}$ & 1 day \\
\hline 57 & M & Pilonidal abscess & IE & $\begin{array}{l}\text { Excision } \\
\text { Discharge }\end{array}$ & 1 day \\
\hline 35 & $\mathrm{~F}$ & Acute appendicitis & IE & $\begin{array}{l}\text { Laparoscopic appendicectomy } \\
\text { Discharge }\end{array}$ & 1 day \\
\hline 33 & M & Acute appendicitis & IE & $\begin{array}{l}\text { Laparoscopic Appendicectomy } \\
\text { Discharge }\end{array}$ & 1 day \\
\hline 83 & M & Pseudoobstruction & IIIE & Colonic decompression & 4 days, icu \\
\hline 33 & F & Biliary colic & IIE & $\begin{array}{l}\text { Laparoscopic Cholecystectomy } \\
\text { Discharge }\end{array}$ & 5 days \\
\hline 64 & M & Acute Cholecystitis & IIIE & $\begin{array}{l}\text { Laparoscopic } \\
\text { Cholecystectomy Cholangiogram } \\
\text { Discharge }\end{array}$ & $\begin{array}{l}5 \text { days } \\
\text {-CBD Calculi } \\
\text { ERCP }\end{array}$ \\
\hline 35 & M & Acute appendicitis & IE & $\begin{array}{l}\text { Laparoscopic Appendicectomy } \\
\text { Discharge }\end{array}$ & 2 days \\
\hline 22 & M & Abdominal wall abscess & IE & $\begin{array}{l}\text { Incision and Drainage } \\
\text { Discharge }\end{array}$ & 1 day \\
\hline 48 & M & Thrombosed hemmorhoid & IIE & $\begin{array}{l}\text { Hemmorhoidectomy } \\
\text { Discharge }\end{array}$ & 1 day \\
\hline 41 & M & Thrombosed hemmorhoid & IE & $\begin{array}{l}\text { Hemmorhoidectomy } \\
\text { Discharge }\end{array}$ & 1 day \\
\hline 40 & F & Acute cholecystitis & IIE & $\begin{array}{l}\text { Laparoscopic } \\
\text { Cholecystectomy } \\
\text { Cholangiogram } \\
\text { Discharge }\end{array}$ & 2 day \\
\hline
\end{tabular}

Second morbidity was in an elderly patient who required indwelling catheter for 48hours following laparoscopic appendicectomy and washout for perforated appendicitis.

There was no mortality in the operative subgroup.

\section{Discussion}

Health care system in Australia is a mixture of both public and private providers [5]. Acute care surgery is defined as the urgent assessment and treatment of non-trauma general surgical emergencies involving adult patients. The realistic delivery of an acute care surgery model requires a dedicated hospital-based service that provides comprehensive care for all general surgical emergencies over a defined period of time.

Acute Care Services are now an integral part of most central and some peripheral public hospitals in Australia and New Zealand. With increasing demands in the public hospital system on these services there is a potential delay in access to theatres thus leading to an increase in the length of hospital stays4.

This defeats the purpose of the acute care model. In order to tackle this issue, we set up a dedicated unit to evaluate the outcomes of acute care surgery in a private hospital setting. This is an attempt to evaluate outcomes of acute care surgery model in a private hospital setting.
The application of a dedicated roster made it easy for the emergency department to get access to acute care surgeons not only over a 24-hour period but also on the weekends.

As in the public hospital system this was a consultant driven process so there was minimal delay in patients being processed through the emergency department.

Theatre access which has been hurdle in the public system was not an issue in this study as all patients requiring intervention were managed within 24 hours of their admission.

In addition, two of the co investigators in this study had routine lists in the hospital almost every day of the week so it was easy to accommodate patients requiring intervention on the end of the routine list.

There was minimal morbidity and no mortality in this study.

\section{Drawbacks}

The duration of the study is only for 6 months which is a short period and has small numbers to prove the efficacy of this model of care on a long-term basis in a private hospital setting.

The three investigators in this study have all been a part of the acute care unit at a public hospital and are well experienced in the management of emergency general surgical patients. 
As all required services are being provided at consultant level there are minimal delays especially in terms of biochemical, radiological investigations, inpatient bed arrangements, theatre and discharge procedures. This does dilute the opportunity for education of the junior staff.

This study does suggest implementation of the Acute Care Surgery model at private hospital set up might lead to a better pathway for emergency general surgical patients.

\section{Funding}

The corresponding author is not a recipient of a research scholarship and the paper is not based on a previous communication to a society or meeting.

\section{References}

1. Committee to Develop the Re organized Specialty of Trauma, Surgical Critical Care, and Emergency Surgery (2005) Acute care surgery: trauma, critical care, and emergency surgery. J Trauma 58: 614-616.

2. Hoyt DB, Kim HD, Barrios C (2008) Acute care surgery: a new training and practice model in the United States. World J Surg 32: 1630-1635. [Crossref]

3. Davis KA, Rozycki GS (2010) Acute care surgery in evolution. Crit Care Med 38 S405-410. [Crossref]

4. Wang E, Jootun R, Foster A (2018) Management of acute appendicitis in an acute surgical unit: a cost analysis. ANZ J Surg. [Crossref]

5. Australia's health (2016) Australian Institute of Health and Welfare2016. Australian Government

Copyright: (C2018 Patel B. This is an open-access article distributed under the terms of the Creative Commons Attribution License, which permits unrestricted use, distribution, and reproduction in any medium, provided the original author and source are credited. 